\title{
Spillover effects of unconventional monetary policy on capital markets in the shadow of the Eurozone: A sample of non-Eurozone countries
}

\author{
Mercédesz Mészáros, ${ }^{1}$ Gábor Dávid Kiss ${ }^{2}$
}

\begin{abstract}
The transmission mechanism has been dominated by direct monetary measures since the crisis of 2008. While the indirect impacts of the unconventional monetary instruments have not been fully explored yet. Monetary policy and funding conditions determine pricing sentiments for bond, stock and currency markets, represented by the volatilities of their main indicators: stock market indices, exchange rates, and yield premia. Our theoretical model takes spillover effects into account when it determines the variables which are responsible for volatility: the activities of international financial institutions (like the ESM or the IMF) are represented by dummy variables, while the limited autonomy in the shadow of the ECB is captured through gravity-like approaches. Six EU member states outside the Eurozone and Switzerland were analysed between 2007 and 2019 with random effect panel regression models to identify the differences in the impact of spillover effects on capital market volatilities. The results obtained are considered to be useful in mapping the potential effects of continuing monetary easing in the near future.
\end{abstract}

Keywords: unconventional monetary policy; QE; spillover effects; capital markets

JEL classification: C33, E43, E44, E52, E58, G15

\section{Introduction}

Nowadays, when the normalisation of monetary policy seems to be hindered by a global economic downturn, it is important to assess the impacts of the unforeseen developments on the capital markets, such as the usage of unconventional monetary instruments. Once conventional monetary policies had reached their limits, central banks had to expand their balance sheets to fight deflation and to restore financial stability as well. While the "lender of last resort" function had to be enhanced by long term lending programs, a new "market maker of last resort" function emerged, as sovereign and private bond accumulation was initiated to restore the efficiency of the transmission mechanism. Parallel to these efforts, a massive sovereign debt restructuring programme was implemented in some EU member states by the International Monetary Fund (IMF) and later by the European Stability Mechanism

${ }^{1} \mathrm{PhD}$ student, University of Szeged, Faculty of Economics and Business Administration, Hungary, m.mercedesz@eco.u-szeged.hu.

${ }^{2}$ habil. $\mathrm{PhD}$; associate professor, University of Szeged, Faculty of Economics and Business Administration, Hungary, kiss.gabor.david@eco.u-szeged.hu.

(C) 2020 by the authors; licensee Review of Economic Perspectives / Národohospodářský obzor, Masaryk University, Faculty of Economics and Administration, Brno, Czech Republic. This article is an open access article distributed under the terms and conditions of the Creative Commons Attribution 3.0 license, Attribution - Non Commercial - No Derivatives. 
(ESM). Bond market investors found themselves in an accommodative environment where demand was being stabilised by the central bank, and unsustainable public debt term-structures were being resolved by the initiation of the ESM. All these steps had a calming effect in the second half of the 2010s, with a slight reduction in the long-term yields.

The liquidity of the stock and bond market got more attention, as the credit crunch caused a gradual decline in corporate loans following the subprime crisis. One explanation for this is that, with the decline in banks' willingness to lend, economic actors started to bypass them by directly financing the corporate sector through the bond market, thus contributing to crisis management. On the other hand, central bank security and asset purchases also began at this time and continued for the rest of the decade. The European Central Bank showed deep commitment towards quantitative easing (QE), but the "stickiness" of the unconventional monetary policy manifested in the continuation of these policies even in 2019 — regardless of the fact that originally these were intended as temporary measures only. The example was even followed by several central banks of small open economies that are more exposed to global liquidity flows than the relativity robust US or the Eurozone.

The performance of the monetary policy is historically evaluated via the variances of macro-variables like inflation and output gap, mostly in the form of policy frontier graphs (Taylor and Williams, 2011). However, this approach can be interpreted for the capital markets as well. The main objective of our research was to identify the extensive impact of the European QE programs on the currency, stock and bond market pricing uncertainties, since the volatility of these markets can be a valuable benchmark for understanding the potential spillover effects of the unconventional monetary policy. Prior research has dealt with these financial and capital market effects of the unconventional monetary policy in many different ways. For example, Haitsma et al. (2016) compared the effects on the stock market caused by traditional measures and by unconventional instruments of monetary policy, and there was even a study which compared the effects generated on the capital market correlations by the different QE programs of the ECB (Kenourgios et al. 2019). As for the European manifestation of QE, the majority of studies on this topic examined the effects within the Eurozone, with only a few covering the non-Eurozone countries (Kucharčuková et al. 2016). There is even less research that analyses the relationship between unconventional monetary policy and its spillovers in the capital markets, in the sample of these less-studied countries (Ciarlone and Colabella, 2018).

This paper fills the gap in the literature by implementing a model which recognises the size differences among the ECB and the sample of European central banks of small open economies in the halo of the Eurozone, the initiation of the various debtrestructuring programs and the applied accommodative security purchase and lending programs. Since volatility can be interpreted as a sign of uncertainty in asset valuation, the calming impact of the aforementioned efforts can be tested considering the possible spillovers and the potential portfolio rebalancing effects. This agenda requires precise identification of the manner in which each of these unconventional instruments was applied, and to what extent, with macro variables which can be relevant for the transmission mechanism. Our aim is to explore the specific aspects of the relationship between $\mathrm{QE}$ and the transmission mechanism in the context of small open economies 
operating in the shadow of the ECB and the ESM. To this end, we attempt to identify the effects of the unconventional monetary policy and debt rescheduling on the currency, stock and bond markets. This analysis could be motivated by the possible continuation of QE, to test a now available 12-year-long, quarterly dataset (from 2007 Q1 to 2019 Q1), so that it can be used to answer some of the 'puzzles' raised in the literature. Monetary policy should focus on the domestic economy, therefore the general aspects of the QE will be introduced in the first theoretical subsection, and then we will continue with its market- and foreign impacts later on. As shown in the literature review, the effects of the ECB's quantitative easing outside the euro area have been inadequately examined, given its direct and indirect impacts on capital markets. For this reason, the examined sample covers the ECB and central banks of small open economies outside the Eurozone that used unconventional instruments during the period under review, such as the Czech Republic, Denmark, Hungary, Poland, Sweden, and Switzerland. ${ }^{3}$ The composition of the sample is motivated by their relative smallness (compared to the Eurozone) while their financial sector is mainly tied to the continent, and they are enjoying the benefits of the free movement of the capital.

This study is structured as follows: the second section summarises the theoretical background of the international spillover effects generated by unconventional monetary policy decisions, introduces QE programs briefly and the methods of international debt restructuring through the sample countries, and contains the theoretical models which will be the subject of further analysis. The third section presents the examined dataset and the summary of conditional volatility models and random effect panel regressions, while the fourth contains the results of the model testing. The final section summarises the main purpose and the conclusions of our study.

\section{Theoretical background}

Suppose that volatility can be interpreted as a sign of uncertain asset valuation, this section summarises the main theoretical approaches of the unconventional monetary policy and its spillovers into capital markets, and also contains a short note on international debt restructuring. After our variables were introduced and justified by the cited literature, the theoretical model was presented, along with the a priori expected signs.

\section{Unconventional monetary policy (UMP) and quantitative easing $(Q E)$}

The position adopted in the years preceding the crisis was that short-term interest rate formation (primarily through open market operations) should be a primary tool for monetary policy, which had sufficient influence long-term interest rates (Blanchard et al., 2015, Tarafás, 2016). Nominally, short-term interest rates $\left(1 Y_{t}\right)$ should respond to inflation, while long-term rates $\left(10 Y_{t}\right)$ respond to output and fiscal outlook of the member states in the Eurozone, as investors are selling short-term treasury bills and reinvesting the proceeds in long-term ones (Hamori and Hamori, 2010; Ellison and Tischbirek, 2014). The steepness of the yield curve (1) provides information not only about macro-expectations but about the liquidity as well:

3 The United Kingdom was excluded from the sample because its size, heavily globalised financial markets and policy actions — during the analysed period—would have biased the results. 
$10 Y_{t}-1 Y_{t}>0$

Interest rate policy exerts an indirect effect on foreign exchange (fx) rates through the exchange rate channel of the monetary transmission mechanism, which is of particular importance for small, open economies due to tradable goods prices and balance sheet currency mismatches (Frankel, 2011; Felcser et al., 2015). However, capital flows are the subject of investors' risk appetite as Fratzscher (2012), and Kiss and Szilágyi (2014) pointed on the increased demand for safe-haven currencies after the outbreak of the subprime crisis: capital had typically moved toward to safer investments, which had resulted in frequent "sudden stops" in the financing of emerging market economies (Habib and Stracca, 2012, Ranaldo and Söderlind, 2010).

Central banks introduced unconventional monetary instruments on their own to achieve their objectives, in the wake of financial market turmoil or a crisis (Gertler and Karadi, 2011; Krekó et al., 2012; Thornton, 2014). Having pursued the zero interest rate policy, which was used to alleviate the liquidity crisis, there was no possibility of further easing using conventional instruments. So central banks turned to forward guidance to affect expectations, and other unconventional measures with structural impact on their balance sheets like qualitative and quantitative easing (Bernanke and Reinhart, 2004; Joyce et al., 2012). Through forward guidance, monetary decision-makers tried to bring the expectations of market participants closer to the goals and expectations of the central bank, based on its credibility. Quantitative easing increases the central bank's balance sheet $(C B B S)$ in time $t$, aimed at the liability side while leaving the asset side structurally unaffected, with the composition of fx reserve $(F X)$, domestic lending $(L)$, domestic securities $(S)$ and other assets $(\kappa)$ unchanged (2). This is the expansion of the monetary base to stimulate aggregate demand (Ito, 2014).

$C B B S=F X+S+L+\kappa$, where $\frac{C B B S_{t}}{C B B S_{t-1}} \cong \frac{F X_{t}}{F X_{t-1}} \cong \frac{S_{t}}{S_{t-1}} \cong \frac{L_{t}}{L_{t-1}}$

In contrast, the qualitative easing aims to adjust the structure of the asset side of the balance sheet (3), but it does not always entail a change in the size of the balance sheet (Borio and Disyatat, 2010; Krekó et al., 2012).

$\frac{C B B S_{t}}{C B B S_{t-1}} \cong 0$ while $\frac{F X_{t}}{F X_{t-1}} ¥ \frac{S_{t}}{S_{t-1}} ¥ \frac{L_{t}}{L_{t-1}}$

Together, all these approaches are referred to as Quantitative Easing (QE), a policy adopted by the leading central banks (Fed, BoJ, BoE, ECB), with large-scale asset (mainly treasury bonds and mortgage-based securities) purchase programs, complemented by their various long-term credit market ${ }^{4}$ interventions (lending with longer maturities and accepting riskier collaterals). This combination of the "lender of last resort" and "market maker of last resort" functions aimed the reduction of long-term yields to restore monetary transmission mechanism (Eser and Schwaab, 2016), with an indirect influence on fx rates and funding conditions (Wang et al., 2015; Pál, 2018;

\footnotetext{
${ }^{4}$ Heryán and Tzeremes (2017) stated that the expanded lending affected the larger and more liquid banks in the Eurozone.
} 
Farmer, 2013). This is interpreted in our study as the structural changes among the main asset components (4).

$\frac{L_{t}+S_{t}}{F X_{t}}>\frac{L_{t-1}+S_{t-1}}{F X_{t-1}}$

QE reduces the long-term interest rates, improves creditworthiness, and enhances the reserve accounts of central banks. In many cases, these programs initiated a structural change in some earlier foreign currency reserve oriented balance sheets through the purchase of securities and wider lending activities (Bernanke, 2012; Czeczeli, 2017), which had broader spillover effects (Pál, 2018). This was true for Europe as a whole, where were remarkable differences in the timing and in the level of commitment towards the different QE instruments, based on the differences in fundamentals and market sentiment in each sample economy (Table 1).

Table 1. The application of unconventional instruments (2007-2018)

\begin{tabular}{lccccccc}
\hline instrument central bank & $M N B$ & $N B P$ & $C N B$ & $S N B$ & $D N$ & $S R$ & $E C B$ \\
\hline asset purchase programs & $\bullet$ & & & & & $\bullet$ & $\bullet$ \\
forward guidance & $\bullet$ & $\bullet$ & $\bullet$ & $\bullet$ & $\bullet$ & $\bullet$ & $\bullet$ \\
negative interests & $\bullet$ & & & $\bullet$ & $\bullet$ & $\bullet$ & $\bullet$ \\
quantity limits on refinancing & $\bullet$ & $\bullet$ & & $\bullet$ & $\bullet$ & $\bullet$ & \\
FX swap & $\bullet$ & $\bullet$ & $\bullet$ & $\bullet$ & $\bullet$ & $\bullet$ & $\bullet$ \\
interest swap & $\bullet$ & & & & & & \\
targeted lending & $\bullet$ & & & & & & $\bullet$ \\
FX ceiling & $\bullet$ & & $\bullet$ & $\bullet$ & & & \\
asymmetric interest channel & $\bullet$ & $\times$ & $\boldsymbol{\checkmark}$ & $\boldsymbol{\checkmark}$ & $\boldsymbol{\checkmark}$ & $\times$ & $\times$ \\
\hline FX flooring or pegging & $\times$ & $\times$ &
\end{tabular}

Source: authors' computation, based on the CBs' press releases after monetary council meetings

There were common instruments like the policy of forward guidance or FX swaps, while asset purchase programs were mostly introduced in the case of the ECB, SR, and later by the MNB. The last line shows which central bank applied direct exchange rate regulations during the period under review. As for the direct flooring of exchange rates, Denmark follows a fixed exchange rate regime (a tight peg since the 1990s), while Switzerland adopted an upper ceiling between 2012 and 2015, and Czechia maintained

\footnotetext{
${ }^{5}$ Notes: list of abbreviations;

MNB: Magyar Nemzeti Bank (Hungarian National Bank)

NBP: Narodowy Bank Polski (Polish National Bank)

CNB: Ceská Národní Banka (Czech National Bank)

SNB: Swiss National Bank

DN: Danmarks Nationalbank (Danish National Bank)

SR: Sveriges Riksbank (Swedish National Bank)

ECB: European Central Bank
} 
a similar regime between 2013 and 2017. But what happened when unconventional monetary policy did not only restore the transmission mechanism but unwantedly impacted other markets as well?

\section{QE influence on capital markets}

This section summarises the recent literature on the direct and indirect impacts of the unconventional monetary policy, with domestic and foreign effects. Liquid bond markets contribute to improving the efficiency of monetary transfers, and a sufficiently liquid and developed bond market could improve financial stability and mitigate the effects of a potential economic crisis. On the other hand, QE is not for everyone: it requires a deep and liquid bond market and securitisation in general in the banking sector, with a highly developed reporting culture, which needs further development in the Eastern member states (Lippai-Makra et al., 2019, Sági-Lentner 2019). Overshooting the QE in a small and open economy can possibly expose them further to dependency on international capital flows.

Further QE works basically through 3 layers: it has an impact on the economy through the portfolio restructuring effect, from a fiscal impact, and its impact on the expectations of market participants (Woodford, 2012; Maggio et al., 2016). The strength of these effects is related to the size of the QE programs and the maturity structure of the purchased securities, through the exploitation of market imperfections - which fact supports a more detailed examination in a later research of the composition of central bank securities (Bernanke et al., 2004; Woodford, 2012).

Starting with the Bank of Japan and the Federal Reserve, Wang et al. (2015) studied the central banks' QE effectiveness via the tail risks of stock markets in the U.S., Japan and other 74 countries, using value at risk (VaR) methods, adopting the extreme value theory. Besides, they revealed the announcement-day effect on the American and Japanese stock markets, and they proved that QE policies have aggravated the tail characteristics of the stock return distributions. Moreover, they showed that the risk of stock returns is influenced differently by these new measures and that both monetary easing programs had a similar effect on the tail characteristics of return distributions. About the responses of stock markets to the Fed's unconventional actions, Eksi and Tas (2017) demonstrated that at ZLB, the response of stock returns to monetary policy operations is almost 7 times higher than at bigger Federal funds rates. They showed that investors rebalanced their portfolios towards equity after selling longer-term assets to the Fed during the large scale asset purchase programs (LSAPs), which increased the demand for stocks and raised stock prices.

About the spillover effects of QE implemented by the ECB, Kenourgios et al. (2019) found significant differences in the correlation between bonds or stock market indices and currency forwards across the period of the SMP, OMT, CBPP3 and PSPP programs, in accordance with the results of Kryzanowski et al. (2017) and Steeley (2017). Their research proved too that unconventional instruments had an impact on the correlations between financial assets through the portfolio rebalancing channel, as other earlier studies have shown (Falagiarda et al., 2015; Varghese and Zhang, 2018; Albertazzi et al., 2018). They also showed that, although the correlations between stock index and currency forwards have been influenced to a higher extent in the case of 
emerging markets, the developed markets have been affected more than the emerging markets. In an earlier study, Kholodilin et al. (2009) examined the impact of the ECB's unconventional policies on the European stock market, using the heteroscedasticity based approach of Rigobon (2003) and an event study approach. Their result showed that in the Eurozone, the ECB's monetary policy had a heterogeneous effect on the sectoral stock market indexes. Regarding the recent unconventional monetary policy of the ECB, Eser and Schwaab (2016) examined the Securities Market Programme (SMP) generated impacts on yields, for a sample of 5 sovereign bond markets in the Eurozone. Using panel data regression, their findings proved that asset purchases raised the level of liquidity and lowered default-risk premium. They also verified the "announcement effect", which resulted in lower bond yield volatility on intervention days. But despite these beneficial effects, some European bond yields began to rise again after the initial announcements and after expanding the program to other countries. However, following the spread of the sovereign debt crisis, the ECB subsequently introduced other similar programs.

There are some recent studies that further scan the effects of the ECB's monetary policy within the Eurozone. Fausch and Sigonius (2018) investigated the impact of this on German excess stock returns, using an event study and VAR models, where they demonstrated empirically that UMP has a significant impact on stock markets. The main outcome of their work was that the overall German stock return volatility mainly expressed the expectation-revisions about future dividends, since the applied interest rate regime determines the stock market response to monetary policy shocks. Haitsma et al. (2016) also conducted an event study to examine stock market responses to the ECB's policy during 1999-2015. Their results confirmed the spillover effect of both conventional and unconventional monetary policies and highlighted the stronger impact of the latter measures on the European stock market. They discovered, inter alia, that the impact of ECB policy changes on the portfolios, constructed on the basis of momentum, is time-variant and differs across the crisis and non-crisis periods. Jäger and Grigoriadis (2017) examined the effectiveness of the ECB's unconventional monetary policy through a comparative analysis between crisis and non-crisis for a sample of 11 Euroarea countries. By calculating pooled OLS estimations for the period from 2007 to 2013, they manifested a significantly negative, reducing effect on the sovereign bond yield spreads for the Eurozone countries. Their other important finding was that the various QE programs and other unconventional instruments had different impacts on crisis and non-crisis countries.

All these findings raise questions about the sustainability of stock (and general asset) market performance: was it the product of the improved expectations about future cashgeneration capabilities, or was it due to the liquidity inflows driven by the portfoliorebalancing effect?

\section{Cross market spillovers}

The purchase of securities and assets by central banks would not normally be considered an unconventional intervention, but because these have an impact on the size and the structure of the central bank balance sheet, they qualify to be termed as such. $\mathrm{QE}$ also affects financial markets and thus generates global effects beyond the country concerned. As a result, a central bank should not only bear in mind targeted inflation 
and the output, but also the potential spillover effects on financial markets and commodity prices. This section summarises the domestic and international cross-market spillover effects of UMP and QE, to extend the well-known uncovered interest parity $\left(10 Y_{i, t}-10 Y_{D E, t}\right)$ with additional variables that also may guide asset pricing.

Central bank balance sheet expansion under QE helps to increase the prices of highquality assets by stabilising their demand (Shirai, 2014). The indirect effects of UMP have been one of the most interesting topics of recent research, in which, in addition to the similarities, there were significant differences depending on the means the central banks applied and the effects on the examined economies. However, only a few papers examined the capital market effects of the UMP outside the euro area. Kucharčuková et al. (2016) applied VAR model and factor analysis to compare the macroeconomic effects of the two monetary policy regimes on the Eurozone, but also examined its spillover effects on six non-Eurozone EU countries. Their results showed that exchange rates outside the euro area responded faster to unconventional policies, and the responses in many countries turned in the opposite direction, rather than following conventional monetary instruments. In a sample of Central, Eastern, and Southeastern European economies (CESEE ${ }^{6}$ ), Ciarlone and Colabella (2018) examined the impact of ECB's Asset Purchase Program (APP) on the financial markets. Their results proved that these measures appreciated the currencies against the EUR and increased the value of the domestic stock market indices in the short term. Moreover, they found that these instruments had a positive impact on mutual fund investment flows, while their longterm sovereign yields decreased modestly. They also showed that the outright purchase of financial assets supported cross-border capital flows and that these instruments reduced both policy and long-term interest rates to levels well below those predicted. One of the main explanations for the differences is that countries were affected differently by the crisis, and their recovery was varying too-depending on the financial institution development, economic opportunities, and other indicators. Differences in the size of the economies determined the differences in the balance sheet and the level of monetary autonomy as well, limiting the degree of freedom to pursue the domestic needs and the feedback on capital flows and fx rate changes. Since our sample contains the Eurozone, which can be considered as a big and slightly open economy, and the remaining six countries can be viewed as small and open economies, potential spillover effects can be captured through the differences between balance sheet sizes (5). This variable adds possible asymmetries to our model, providing a gravity-like interpretation.

$$
\mathrm{CBBS}_{\mathrm{ECB}, \mathrm{t}} * C_{1, t} \gg \mathrm{CBBS}_{\mathrm{i}, \mathrm{t}} * C_{i, t}
$$

For example, Gagnon et al. (2017) looked for the domestic and cross-border direct and spillover effects of Fed's UMP and FX policies and they found that foreign asset purchases have a significant impact on current accounts - which was reduced as capital mobility was rising and then spilled over into financially integrated countries. Meanwhile, domestic asset purchases have an impact on current accounts too, but only when capital mobility is weak. The spillover effects of unconventional instruments are stronger under greater capital mobility and deeper financial markets, and these effects

\footnotetext{
${ }^{6}$ Non-Eurozone: Bulgaria, Croatia, Czech Republic, Hungary, Poland, Romania and potential EU candidates, like: Albania, Bosnia-Herzegovina, the FYR of Macedonia, Montenegro and Serbia (Ciarlone and Colabella 2018)
} 
are often more articulated in foreign bond yields rather than in fx rates (Gagnon et al., 2017). This study uses the standardised flow of portfolio investments $\left(\frac{\mathrm{PF}_{\mathrm{i}, \mathrm{t}}-\mu_{\mathrm{PF}_{i}}}{\sigma_{\mathrm{PF}_{\mathrm{i}}}}\right)$ to capture the changes in the investors' sentiment, following Frankel (2011).

Fratzscher et al. (2016) examined the impact generated by the unconventional monetary policy of the ECB, using panel models. Their main findings were that these actions mainly affected financial markets in the Eurozone, where they had an advantageous impact on asset prices. Still, they also had a positive spillover into international markets by reducing market fragmentation in bond markets. Overall, their study confirmed that there were beneficial impacts on global financial markets in the short term, thanks to the unconventional ECB policies, which later lifted global asset prices and decreased the global price of risk.

Monetary policy-currency market interactions were studied largely with a focus on direct and indirect interventions, where exchange rate volatility was considered as a side-effect of the interest rate differentials: exchange market pressure (Stavárek, 2010) which considers FX, M2, fx and interest premium volatilities, while Gabrisch (2017) identified monetary autonomy limitations on a similar set of countries during his study about interest rate and exchange rate co-movements. Tamakoshi and Hamori (2014) pointed to the asymmetric behaviour of correlations, as they were higher during joint appreciation periods of the US dollar (USD), the euro (EUR), and the Swiss franc (CHF). Meanwhile, Aizenman et al. (2016) suggested that exchange rate stability depends on current account balance, gross national debt, foreign trade, or financial development. The excessive appreciation of the CHF and CZK was limited through the implementation of temporary exchange rate floors around the middle of the decade to prevent deflation (Brůha and Tonner, 2018), while Denmark followed a narrow-pegged arrangement. Ours was a balanced sample with three fixed-type and three non-fixed currencies, where the lack of floating was represented with the (dFX regime $\left.{ }_{i, t}\right)$ dummy variable.

Moreover, the spillover effects of central bank measures not only affect exchange rates but also affect stock prices through a variety of other channels which, through their impact on the real economy, may require new monetary policy measures and may even be counter-productive (Jammazi et al., 2017). An example of this is that the expected decline in the stock prices may indicate weaker performance in the real sector, which may lead to a reduction in the key interest rate (Jammazi et al., 2017). The relationship between fx and stock market prices can be examined in terms of the "international trading effect", according to which the development of fx rates has a different effect on the competitiveness of export and import oriented companies, which influences their performance and value, and through this effect also influences the movement of stock prices (Aggarwal, 1981; Csiki and Kiss, 2018). From another perspective, through the "portfolio balance effect", stock prices influence the development of fx rates through the effects on yield premia (Goldstein et al., 2018). This has been studied by several researchers, regarding the effects of $\mathrm{QE}$, with different results for central banks. 


\subsection{International debt restructuring}

In the case of smaller and fundamentally weaker countries, which were more affected by the crisis, the success of the crisis management has in many cases been significantly contributed by the grants and loans received from international organisations or the EU. In our sample, the International Monetary Fund (IMF) and the European Stability Mechanism (ESM) were the main players providing targeted credit agreements for the European small open economies.

There were different waves of debt restructuring programs in the Eurozone, supporting sovereign debt reorganisation and bank recapitalisation after 2008. The IMF funds itself from loans provided by its sovereign members and conducts lending mainly with a maximum duration of ten years since 1946, while the recently established ESM raises capital from bond-issuance with member state guarantees and provides a 50-year repayment period for its loans (Kiss et al., 2019). The consolidation period started in 2010 with a bilateral loan and an IMF package to Greece, which was continued through 2012 until 2015, when the ESM debuted and the country was able to return to market financing in 2018. Cyprus was funded by the IMF and later by the ESM after 2012 for similar reasons as Spain in 2012 or Ireland after 2010: to finance the burden of banking recapitalisation and to finance the budget deficit. These programs contributed to decreasing the yield premia of the countries on the Eurozone periphery and dispersed the term-structure of the sovereign debt (Pelle and Végh, 2019). All these programs can be considered as exogenous shocks for the sample economies and will be represented by dummy variables $\left(d E S M_{i, t}\right.$ and $\left.d I M F_{i, t}\right)$.

\subsection{Theoretical Model}

Asset pricing is based on expectations about fundamentals, while pricing-bubbles may seriously destabilise a market to the point where monetary policy will be constrained by the ZLB (Robinson and Stone, 2006). Monetary policy and funding conditions tend to guide pricing sentiments both on bond, stock and currency markets, represented by the volatility of their main indicators. Since bond markets can be represented well by their yield premiums, as the divergence-theory suggests, both yield volatility and yield premium will be analysed. Ongoing international debt restructuring programs in the Eurozone and fx ceilings can improve market certainty about asset pricing, so our model is initiated with these dummy variables (6a). The research design is based on four variable groups: (6b) capital flow (with interest rate premium and portfolio investments), (6c) QE (loans and securities to fx reserves ratio and balance sheet growth), (6d) spillover (yield curve steepness in the Eurozone, differences between central bank balance sheet sizes) and (6e) macro-conditions (deviation from targeted inflation, output gap). These groups are tested alone and together (6 a-e) to evaluate their importance.

Our theoretical model takes spillover effects into account when determining the variables which are responsible for market concerns about the accuracy of pricing, represented by conditional volatility. They can be the result of the activities of international financial institutions (like the ESM or the IMF), or they can be the result of "agglomeration effects", since all sample central banks are operating in the shadow of the ECB, which reduces their autonomy. That is the reason for the inclusion of lending- 
related dummies for all the quarters when the ESM or the IMF provided loans to any of the Eurozone member states. Meanwhile, since the ECB's security market and asset purchase programs targeted the yield curve steepness and inflated its balance sheet, these variables follow a gravity-like representation.

$$
\begin{aligned}
& \Delta \sigma q_{i, t}=\text { const. }+\beta_{1} d E S M_{i, t}+\beta_{2} d I M F_{i, t}+\beta_{3} d F X \text { regime }_{i, t} \\
& +\beta_{4} \Delta\left(10 Y_{i, t}-10 Y_{D E, t}\right)+\beta_{5} \Delta\left(\frac{P F_{i, t}-\mu_{P F_{i}}}{\sigma_{\mathrm{PF}_{\mathrm{i}}}}\right) \\
& +\beta_{6} \Delta\left(\frac{L+S}{F X}_{i, t}\right)+\beta_{7} \Delta\left(\frac{B S_{i, t}}{B S_{i, 1}}\right) \\
& +\beta_{8} \Delta\left(10 Y_{E Z, t}-1 Y_{E Z, t}\right)+\beta_{9} \Delta \ln \left(B S_{E C B, t} * C_{1, t}-B S_{i, t} * C_{i, t}\right) \\
& +\beta_{10} \Delta\left(\pi_{i, t}-\pi_{i}^{*}\right)+\beta_{11} \Delta\left(\text { opg }_{i, t}\right)+\varepsilon_{i, t}
\end{aligned}
$$

where

$\sigma q_{i, t}\left\{\begin{array}{c}\overline{\sigma m_{l, t: t+2, P}} \text { for } P_{i, t} \text { long term bond premium, where } P_{i, t}=10 Y_{i, t}-10 Y_{D E, t} \\ \overline{\sigma m_{l, t: t+2, S}} \text { for } S_{i, t} \text { stock market indices } \\ \overline{\sigma m_{l, t: t+2, C}} \text { for } C_{i, t} \text { currencies in } X A U\end{array}\right.$

The a priori expected signs for the model are as follows:

The ESM and IMF funding-related dummies should calm markets, as they are the indicators of ongoing consolidation from international, non-market funds, so the $\beta_{1}$ and $\beta_{1}$ coefficients can have a negative value. The maintenance of exchange rate flooring or pegging is a direct indicator of exchange rate smoothing (and marks the possibility that the currency is considered a safe haven); however, flooring allows downward volatility as well. Regime changes must be included in the model, but the anticipated value of the $\beta_{3}$ the coefficient can hardly be considered as negative.

The risk premium represents an indirect incentive to motivate capital inflow, which can stabilize the market $\left(\beta_{4}<0\right)$ demand as long as asset purchase programs and excessive market sentiment changes are not frittering away its power. The standardised flow of portfolio investments represents the appetite of foreign investors, where their inflow stabilises the demand in the bond and stock markets $\left(\beta_{5}<0\right)$, but it can lead to excessive appreciation in the currency markets $\left(\beta_{5}>0\right)$.

$\mathrm{QE}$, with the structural increase of the lending and securities to fx reserve ratio, can be considered as a key factor to calm bond markets through asset purchases $\left(\beta_{6}<0\right)$, which is extended to the stock markets through the portfolio-rebalancing effect. However, it is also possible that it increases currency volatility as it can be considered as an additional easing $\left(\beta_{6}>0\right)$. The growth rate of a central bank's balance sheet (base: 2007 Q1) is another indicator of $\mathrm{QE}$, with a similar calming impact on the bond and stock markets $\left(\beta_{7}<0\right)$ as well as the currency markets $\left(\beta_{7}>0\right)$.

One indicator of the spillover effects of the ECB's QE was the steepness of the yield curve in the Eurozone, where a positive value can be the sign of nominal operations 
$\left(\beta_{8}<0\right)$. The relative size of the central bank balance sheet (denominated in XAU) represented the asymmetry among the sample central banks and the ECB, indicating that smaller central banks can more easily become the subject of higher volatility $\left(\beta_{9}>0\right)$.

To represent the macroeconomic conditions of the underlying economies, the deviation from targeted inflation $\left(\pi_{i, t}-\pi_{i}^{*}\right)$ was added since the entire sample follows a price stability objective. Since the sample period can be characterised by deflation, the appearance of any inflation can be considered as a sign of economic normalisation $\left(\beta_{10}<0\right)$. An output gap (HP filtered from $I$ industrial production index: $o p g_{i, t}=$ $\left.H P(I)_{\lambda=100}-H P(I)_{\lambda=1600}\right)$ represents the case of economic recovery from the state of recession $\left(\beta_{11}<0\right)$.

\section{Data and methods}

This section first presents the sources and the developments in the analysed dataset. Then it summarises the methodological backgrounds of the applied conditional volatility models and random effect panel regression. The aim of this paper is to investigate the background of volatility changes in stock, bond, and currency markets, which can be estimated via GARCH models.

\section{Data}

Data (Table 2.) was collected mainly from central bank databases, Eurostat and stooq.com, covering the period from 2007 Q1 to 2019 Q1. All FX data used gold (XAU) as the denominator to avoid the interactions with the US Fed's monetary policy as creating a possible bias under USD denomination. Balance sheet data was denominated in XAU from the same consideration, too.

Table 2 Data sources

\begin{tabular}{ll}
\hline Variable (2007Q1-2019Q1) & Source \\
\hline FX rates (denominated in XAU) & stooq.com \\
Interest rate: 10-year sovereign yield (10Y) + premia & stooq.com \\
Output gap (industrial production index, HP filter) & OECD, Eurostat \\
Portfolio investments & central banks, Eurostat \\
Deviation from inflation target & central banks, Eurostat \\
CBBS: Balance Sheet size (in XAU) & central banks (Balance sheet data) \\
LSFX = (L+S)/FX reserve ratio & central banks (Balance sheet data) \\
FX regime dummy & central banks (Annual reports) \\
ESM dummy / IMF dummy & ESM / IMF \\
Stock indices & stooq.com \\
Yield curves & Eurostat, ECB database \\
\hline
\end{tabular}

Source: Authors' edition

The standard deviations of interest rates and interest premiums were calculated against German 10Y government bond yields because the $10 \mathrm{Y}$ maturity is less affected by liquidity turbulences or monetary policy decisions. Following Demir (2014), due to data 
availability and flexibility, the output gap was calculated from the industrial production index against its HP filtered values. First differences were used for all variables, and they were tested against unit root by the Im, Pesaran and Shin (2003) test, as the results in Table 3 present. The balance of portfolio investments and the deviation from inflation target are important macro-variables, especially in the case of small open economies, wherein changes can have a significant impact on currency markets and asset prices, for example, through the "flight-to-safety" phenomenon.

Unconventional monetary policy was captured by incorporating balance sheet variables (CBBS, LSFX) into our models. Central bank balance sheets presented a continuous but country-specific growth in the sample, wherein value can be affected by lending expansion, security accumulation programs, and FX reserve changes due to UMP interventions. The balance sheet of the ECB showed a notable rise after the introduction of its QE program, while the Swiss and Czech national banks fought against excessive appreciation. However, structural changes in the balance sheet brought about by UMP are indicated by the LSFX ratio, because securities and lending had mixed importance in the sample, compared to the fx reserves. ECB, CNB, DN and SR presented an expansionist subset, while MNB, PNB and SNB showed a more conservative and FXreserve oriented case. The balance sheets of the ECB and the central banks of Denmark and Switzerland were less FX reserve oriented, but the first two were later pressurised by their inflating reserves. Meanwhile, the ECB continued to expand their lending and securities programs, followed later by the Sveriges Riksbank and the Hungarian National Bank. The Polish and Czech national banks presented some outbreaks in the early period of the subprime crisis.

To quantify the volatility changes in capital markets, standard deviations of stock market indices and the volatility of yields and yield premiums, and the indicators about the slope of the yield curve were added to our database. Two dummy variables were introduced in our calculations to enable measurement of the effects generated by the targeted grants and loans received from the IMF and the ESM, and a third dummy variable to represent the direct fx interventions (FX flooring, fixed FX regime) in our sample.

\subsection{Methods}

Two econometric approaches were applied in our paper: conditional volatility was estimated via GJR-GARCH(p,o,q) model to provide one of the input variables, while the theoretical model was tested with the Fixed effect (FE) panel model. This subsection presents the theoretical characteristics for these approaches.

Conditional volatility models are able to capture the time-variant nature of exchange rate volatility, presenting also the changes in market sentiment and uncertainties about pricing. These can be estimated by $\operatorname{GARCH}(p, q)$ models, especially using one of its asymmetric derivatives for currencies, like the GJR-GARCH(p,o,q) model (7):

$$
\begin{aligned}
& \left\{\begin{array}{l}
S_{t-i}^{-}=1, \text { if } \varepsilon_{t-i}<0 \\
S_{t-i}^{-}=0, \text { if } \varepsilon_{t-1} \geq 0
\end{array}\right. \\
& \sigma_{t}^{2}=\omega+\sum_{i=1}^{p} \alpha_{i} \varepsilon_{t-i}^{2}+\sum_{i=1}^{o} \gamma_{i} S_{t-1}^{-} \varepsilon_{t-i}^{2}+\sum_{i=1}^{q} \beta_{i} \sigma_{t-i}^{2}
\end{aligned}
$$


where $\alpha_{1}>0(i=1, \ldots, p), \gamma_{i}+\alpha_{i}>0(i=1, \ldots, o), \beta_{i} \geq 0(i=1, \ldots, q), \alpha_{i}+$ $0,5 \gamma_{i}+\beta_{k}<1(i=1, \ldots, p, j=1, \ldots, o, k=1, \ldots, q)$ (Greene 2003). This paper used monthly data to fit the GJR-GARCH $(1,1,1)$ models and calculated quarterly means on them to overcome the problem whereby quarterly data had remarkably poor variance persistence due to low frequency.

The research was carried out with the fixed effect (FE) panel model, using the Eviews 11 software. The main reason for the application of this methodology was that it fit the scope of our research topic perfectly, and there are several examples in the previous literature of studying the effects of unconventional monetary policy through different panel regressions. For example, Fassas and Papadamou (2018) analysed the role of unconventional monetary policy announcements in risk aversion by using panel data analysis to investigate the risk-taking channel of monetary policy for the major European and U.S. equity markets, and their findings proved that easing monetary policies can significantly lower the variance premium. Hofmann and Takáts (2015) applied fixed-effects panel regression in their study and found that U.S. short- and longterm interest rates had a significant impact on the corresponding rates in other countries and that these spillover effects reflect in part policy spillovers. As previously mentioned, Eser and Schwaab (2016) inter alia evaluated the yield impact of ECB's securities market programme by fixed effect panel regressions and found that these asset purchases reduced liquidity risk premia through making a significant contribution to ending the sovereign crisis.

Panel regression (Greene, 2003) can be used in respect of databases in which the attributes of several units as cross-sections (in this case markets and central banks, $N$ ) and several periods $(T)$ can be collected, while the specific attributes of the individual that are constant over time need not be observable, because constant factors are dropped from the estimated equation. In cases where a $x_{i}$ explanatory variable correlates with the non-observed $u_{i}$, the application of the fixed-effect model (FE) will be required, as the variables are different, but the time-invariant (8):

$y_{i, t}=\omega+u_{i}+\beta X_{i, t}^{\prime}+\varepsilon_{i, t}$

According to the null hypothesis of the Hausman test, there is no correlation between the $u_{i}$ and $x_{i}$ variables, which means we prefer the FE model for $\mathrm{p}<0.05$ cases. Otherwise, we have to apply the random effect model (RE), which assumes no correlation, as all variables are time-variant and different from each other (9):

$y_{i, t}=\omega+\beta X_{i, t}^{\prime}+\left(u_{i}+\varepsilon_{i, t}\right)$

Panel regressions require stationary input, which was tested with the Im, Pesaran, and Shin (2003) tests $(\mathrm{p}<0.05)$.

The interference between the standard deviation of the yield premium and the change of interest premium could have raised the problem of endogeneity, where the change of interest premium can correlate with the error term under (6a-b) and (6a-e) setups. However, the correlation between the change of interest premium and $v_{i t, 6 a-b}$ was - 
0.0197 and was -0.0069 with $v_{i t, 6 a-e}$ as well, so that the occurrence of endogeneity was rejected.

\section{Results}

The occurrence of the unit root was rejected first via the Im, Pesaran and Shin (2003) panel unit root test since all the individual ADF tests and IPS statistics rejected the null hypothesis of the unit root.

Table 3 Panel unit root test

\begin{tabular}{|c|c|c|c|}
\hline & Statistic & P-value & Interpretation \\
\hline t_bar & -15.7460 & & mean of individual ADF statistics \\
\hline W_bar & -57.2428 & 0.0000 & standardized IPS statistic \\
\hline Z_bar & -58.2350 & 0.0000 & $\begin{array}{l}\text { standardized IPS statistic based on the moments of } \\
\text { the DF distribution }\end{array}$ \\
\hline t_bar_DF & -16.9318 & & mean of individual DF statistics \\
\hline Z_bar_DF & -63.0931 & 0.0000 & assumption of no autocorrelation of residuals \\
\hline $\begin{array}{l}\mathrm{d} \quad \text { std } 10 \mathrm{y}- \\
\text { premium }\end{array}$ & -17.1952 & 0.0100 & individual ADF test \\
\hline $\mathrm{d}$ std $10 \mathrm{y}$ & -13.7766 & 0.0100 & \\
\hline d std currency & -17.5165 & 0.0100 & \\
\hline $\begin{array}{l}d \quad \text { std stock } \\
\text { index }\end{array}$ & -16.3377 & 0.0100 & \\
\hline $\begin{array}{l}\mathrm{d} \quad \text { interest } \\
\text { premium }\end{array}$ & -13.7169 & 0.0100 & \\
\hline d YC-slopeness & -14.1271 & 0.0100 & \\
\hline d PF (z-score) & -27.4914 & 0.0100 & \\
\hline d CBBS & -16.0756 & 0.0100 & \\
\hline d LSFX & -22.2119 & 0.0100 & \\
\hline $\mathrm{d}$ inflation gap & -12.3048 & 0.0100 & \\
\hline d output gap & -7.1278 & 0.0100 & \\
\hline$d$ ln size & -11.0702 & 0.0100 & \\
\hline
\end{tabular}

Source: Authorial computation

Focusing on the sample of non-Eurozone open and small economies in the halo of the $\mathrm{ECB}$, the detailed results of the individual and aggregated panel regression models are available in the Appendix, while the compressed version with the number of significant variables and their signs is presented in Table 4. There are four individual regression models to validate the importance of each variable group ( $6 a-b, a-c, a-d, a-e)$, and an aggregated model (6a-e). While the dummy variables have a five-time occurrence in all possible setups, the others have two: one individual and one aggregate.

Only the introduction of ESM measurements had a significant, calming impact on volatility for the currency and bond markets, while IMF lending had no significant impact on market volatility. These results can be explained by the difference in the 
magnitude of the ESM funds and their longer maturities. The implementation of currency floating boundaries had no significant impact on any of the markets.

Focusing on the capital flow variable-group, setting the interest premium had a calming impact on the currencies but caused distortions for bond premiums - first result fits to the uncovered interest rate parity requirements, and the second has a direct impact on the premium, so it fits intuition. Meanwhile, portfolio investment flows had no contribution to the market volatility neither at individual nor at aggregated levels.

The QE can be captured through the structural changes of the central bank assets (measured by the LSFX ratio) and the expansion of the balance sheet size (CBBS). More active lending and security accumulations generated volatility on the currency markets, while the general expansion of the balance sheet increased stock market volatility. It means that the more intense usage of the portfolio rebalancing channel can increase markets' uncertainties about equity and currency valuation. Moreover, both accommodative interest premium cuts and broader QE will promote higher volatility.

Higher yield-curve steepness increases volatility as well with similar magnitude as QE variables. Therefore if the central bank is not able to act against the increasing steepness, the volatility of currencies and bonds will increase - but a counteractive security purchase or lending programme can compensate this effect for currencies only. The relative size of central bank balance sheets mattered in the stock and bond markets: smallness means higher pricing uncertainty in this case. Only the deviation from the targeted inflation had a significant and calming impact on volatility in currency and bond markets, as a sign of normalisation of the macroeconomic environment.

Table 4 Table summarising the changes in dependent variable volatility

\begin{tabular}{|c|c|c|c|c|c|c|}
\hline & \multicolumn{2}{|c|}{ stock market } & \multicolumn{2}{|c|}{ currency } & \multicolumn{2}{|c|}{ yield premium } \\
\hline & $\begin{array}{l}\text { sign. } \\
\text { cases }\end{array}$ & sign & sign. cases & sign & sign. cases & sign \\
\hline $\mathrm{d}$ dependent variable(t-1) & & & 5 & "“_" & & \\
\hline constant & & & 5 & "+" & & \\
\hline dummy ESM & & & 5 & \%_" & 2 & "“_" \\
\hline dummy IMF & & & & & & \\
\hline dummy FX-regime & & & & & & \\
\hline d interest premium & & & 2 & \%" & 2 & "+" \\
\hline$d P F(z$-score $)$ & & & & & & \\
\hline$d L S F X$ & & & 2 & "+" & & \\
\hline$d C B B S$ & 2 & "+" & & & & \\
\hline dYC-steepness & & & 2 & "+" & 1 & "+" \\
\hline$d$ ln size & 1 & "+" & & & 1 & "+" \\
\hline d inflation-gap & & & 2 & \%" & 2 & ”“-" \\
\hline d output-gap & & & & & 1 & ”-" \\
\hline Durbin-Watson stat $\sim 2$ & $100 \%$ & & $100 \%$ & & $100 \%$ & \\
\hline
\end{tabular}

Notes: "sign. cases": the number of significant cases for the specific variable, "sign": "+" denotes coefficient $>0$ cases, "-" denotes coefficient $<0$ cases

Source: Authorial computation 
Our research outcomes show that market uncertainties about asset pricing were mainly calmed by the ESM lending even outside the targeted area, whereas the monetary policy had an opposite impact. The impact of the portfolio rebalancing effect was clear since both the structural changes on the asset side and the expansion of the balance sheet size increased uncertainty as well as volatility. Portfolio investment flows had no significant impact on this, which deviates from the emerging small and open economy model of Frankel (2011). At the same time, discretionary fx ceilings had no cross-country impacts at all. Meanwhile, the asymmetric effects among the sample countries and the Eurozone mattered a lot, punishing the smaller economies, meaning that size actually matters, and staying out of the Eurozone takes its tolls in the form of extra volatility. Whilst currency valuation was the most affected and bond market volatilities were seemingly influenced, stock market volatility was mostly robust on these variables.

\section{Conclusion}

Investigating the spillover effects of unconventional monetary policy is still a popular topic of contemporary economic literature. Originally, QE was designed as a set of temporary measures, but later it became the "new normal". In our study, we have examined the extensive impact on the stock, bond and currency markets of the unusual instruments of monetary policy using a narrowed example of European non-Eurozone central banks and the European Central Bank. Our research was motivated mainly by the observation that the next crisis is approaching, since Europe is currently at the end of a long business cycle. Meanwhile, most of the European central banks have been following "adaptable mild" monetary policies in the shadow of the accommodative ECB. In turn, the expected upcoming changes can be accompanied by internal and external shocks on the continent, which challenges may call for further monetary engagement. Another important fact is that QE programs are being maintained in some countries nowadays, even though it is proved that these actions have unwanted longterm and widespread impact. The analysis of capital market effects is also supported by the fact that a liquid and developed stock and bond market can contribute to the strengthening of financial stability, as risks pertaining to a single company are not concentrated in the financing banks alone but are also distributed among other investors in the bond market. However, our findings were underlying the fact that QE was a source of volatility to some extent.

The main question of our research was to find out whether the ECB's QE programs and unconventional instruments have had an influence on capital markets. Some of the previous research has investigated this issue, but very few studies have examined the case of non-Eurozone countries. To answer this, our paper proposed estimating conditional volatility models and random effect panel regression models to measure which of the variables in the theoretical models had a significant impact on capital markets. Our modelling approach is based on the assumption that both monetary policy and financing conditions tend to steer pricing sentiment in both bond, stock and currency markets, which effect is represented by the conditional volatility. This volatility can be dampened by spillovers caused by international debt restructuring programs and direct fx regulations while improving market certainty, so we started our model by incorporating these dummy variables. Within the scope of our research, we used four additional groups of variables that capture the influence of interest premium, 
QE, spreads, and macro-conditions in our theoretical models. These groups were tested separately and in aggregate to assess their importance for the market's concerns about the accuracy of pricing. In most of the cases, individual models had the same results as our general theoretical model.

Overall, our results have proved that the volatility in stock, bond and currency markets was significantly influenced in the short term by the application of unconventional monetary policy instruments introduced by the central banks over the past decade, such as liquidity-providing credit programs and asset purchases. However, the main findings of our study suggest that the market insecurity about asset prices was primarily mitigated by the assistance of the ESM over the period under review, while monetary policy involved several, sometimes indirect, methods to raise uncertainty and volatility in the capital markets. Meanwhile, the asymmetric effects between the sample countries and the euro area mattered a great deal in terms of creating disadvantages for smaller economies.

Further research in the near future answering several possible questions may be interesting; for example, it would be enlightening to examine how the composition of the stock of securities purchased by central banks changed during the last decade and whether it had more spillover effects. Another interesting question may be whether the assistance from other international organisations has had similar positive effects on other economies, as for the ones we have examined.

Funding: This research was supported by the project nr. EFOP3.6.2-16-2017-00007, titled Aspects on the development of intelligent, sustainable and inclusive society: social, technological, innovation networks in employment and digital economy. The project has been supported by the European Union, co-financed by the European Social Fund and the budget of Hungary.

Disclosure statement: The authors reported no potential conflict of interest.

\section{References}

AGGARWAL, R., (1981), Exchange Rates and Stock Prices: A Study of U.S. Capital Market under Floating Exchange Rates, Akron Business and Economic Review, Vol. 3, No. 9, pp.7-12.

AIZENMAN, J., CHINN, M. D., ITO, H., (2016), Monetary policy spillovers and the trilemma in the new normal: Periphery country sensitivity to core country conditions, Journal of International Money and Finance, Vol. 68, pp.298-330. DOI: 10.1016/j.jimonfin.2016.02.008

ALBERTAZZI, U., BECKER, B., BOUCINHA, M., (2018), Portfolio rebalancing and the transmission of large-scale asset programmes: evidence from the euro area, ECB Working Paper No. 2125. Available at SSRN: https://ssrn.com/abstract=3116084.

BERNANKE, B. S., REINHART, V. R., SACK, B., (2004), Monetary policy alternatives at the zero bound: An empirical assessment, Brookings papers on economic activity, 2004, Vol. 2, pp.1-100. DOI: 10.1353/eca.2005.0002 
BERNANKE, B. S., REINHART, V. R., (2004), Conducting monetary policy at very low short-term interest rates, American Economic Review, Vol. 94, No. 2, pp.85-90. DOI: $10.1257 / 0002828041302118$

BERNANKE, B. S., (2012), Monetary Policy since the Onset of the Crisis, Remarks at the Federal Reserve Bank of Kansas City Economic Symposium, Jackson Hole, Wyoming, 2012.09.31.,

Online: http://www.federalreserve.gov/newsevents/speech/bernanke20120831a.pdf.

BLANCHARD, O., CERUTTI, E., SUMMERS, L., (2015), Inflation and Activity Two Explorations and their Monetary Policy Implications, IMF Working Papers, 2015/230.

BORIO, C., DISYATAT, P., (2010), Unconventional monetary policies: an appraisal, The Manchester School, Vol. 78, pp.53-89. DOI: 10.1111/j.1467-9957.2010.02199.x

BRŮHA, J., TONNER, J., (2018), Independent Monetary Policy Versus a Common Currency: A Macroeconomic Analysis for the Czech Republic Through the Lens of an Applied DSGE Model, CNB Working Paper Series, Czech National Bank, No. 2018/19.

CIARLONE, A., COLABELlA, A., (2018), International Spillovers of Non-standard Monetary Policy: Evidence From Central and Eastern Europe In. FERRARA et al. (eds.), International Macroeconomics in the Wake of the Global Financial Crisis, Springer International Publishing AG, Vol. 46, pp. 271-300.

CSIKI, M., KISS, G. D., (2018), Capital Market Contagion in the Stock Markets of Visegrád Countries Based on the Heckman Selection Model, Financial and Economic Review, Vol. 17, No. 4, pp.23-52.

CZECZELI, V., (2017), Az EKB mennyiségi lazítási programjának tapasztalatai', Európai tükör, Vol. 20, No. 1, pp.103-126.

DEMIR, İ., (2014), Monetary policy responses to the exchange rate: Empirical evidence from the ECB, Economic Modelling, Vol. 39, pp.63-70. DOI: 10.1016/j.econmod.2014.02.024

ELLISON, M., TISCHBIREK, A., (2014), Unconventional government debt purchases as a supplement to conventional monetary policy, Journal of Economic Dynamics and Control, Vol. 43, pp.199-217. DOI: 10.1016/j.jedc.2014.03.012

EKSI, O., TAS, B. K. O., (2017), Unconventional monetary policy and the stock market's reaction to Federal Reserve policy actions, The North American Journal of Economics and Finance, Vol. 40, pp.136-147. DOI: 10.1016/j.najef.2017.02.004

ESER, F., SCHWAAB, B., (2016), Evaluating the impact of unconventional monetary policy measures: Empirical evidence from the ECB' s Securities Markets Programme, Journal of Financial Economics, Vol. 119, No. 1, pp.147-167. DOI: 10.1016/j.jfineco.2015.06.003

FALAGIARDA, M., MCQUADE, P., TIRPÁK, M., (2015), Spillovers from the ECB's non-standard monetary policies on non-euro area EU countries: evidence from an eventstudy analysis, No. 1869. ECB working paper. 
FARMER, R. E. A., (2013), Qualitative easing: a new tool for the stabilisation of financial markets, Bank of England Quarterly Bulletin, Vol. 53, No. 4, pp.405-413.

FASSAS, A. P., PAPADAMOU, S., (2018), Unconventional monetary policy announcements and risk aversion: evidence from the US and European equity markets, The European Journal of Finance, Vol. 24, No. 18, pp.1885-1901. DOI: 10.1080/1351847X.2018.1496943

FAUSCH, J., SIGONIUS, M., (2018), The impact of ECB monetary policy surprises on the German stock market, Journal of Macroeconomics, Vol. 55, pp.46-63. DOI: 10.1016/j.jmacro.2017.09.001

FELCSER, D., SOÓS, G. D., VÁRADI, B., (2015), A kamatcsökkentési ciklus hatása a magyar makrogazdaságra és a pénzügyi piacokra, Hitelintézeti Szemle, Vol. 14, pp.3959.

FRANKEL, J., (2011), Monetary Policy in Emerging Markets, in: FRIEDMAN B. M., Woodford M. (eds.): Handbook of Monetary Economics, Elsevier, pp.1441-1499

FRATZSCHER, M., DUCA, M. L., STRAUB, R., (2016), ECB unconventional monetary policy: Market impact and international spillovers, IMF Economic Review, Vol. 64, No. 1, pp.36-74. DOI: 10.1057/imfer.2016.5

FRATZSCHER, M., (2012), Capital flows, push versus pull factors and the global financial crisis, Journal of International Economics, Vol. 88, No. 2, pp.341-356. DOI: 10.1016/j.jinteco.2012.05.003

GABRISCH, H., (2017), Monetary policy independence reconsidered: evidence from six non-euro members of the European Union, Empirica, Vol. 44, No. 3, pp.567-584. DOI: $\underline{10.1007 / \mathrm{s} 10663-016-9337-3}$

GAGNON, J. E., BAYOUMI, T., LONDONO, J. M., SABOROWSKI, C., SAPRIZA, H., (2017), Direct and spillover effects of unconventional monetary and exchange rate policies, Open Economies Review, Vol. 28, No. 2, pp.191-232. DOI: 10.1007/s11079$\underline{017-9437-0}$

GERTLER, M., KARADI, P., (2011), A model of unconventional monetary policy, Journal of monetary Economics, Vol. 58, No. 1, pp.17-34. DOI: 10.1016/j.jmoneco.2010.10.004

GOLDSTEIN, I., WITMER, J., YANG, J., (2018), Following the Money: Evidence for the Portfolio Balance Channel of Quantitative Easing, Bank of Canada, Staff Working Paper 2018-33.

GREENE, W. H., (2003), Econometric analysis, Pearson Education, India.

HABIB, M. M., STRACCA, L. (2012), Getting beyond carry trade: What makes a safe haven currency?, Journal of International Economics, Vol. 87, No. 1, pp.50-64. DOI: 10.1016/j.jinteco.2011.12.005

HAITSMA, R., UNALMIS, D., de HAAN, J., (2016), The impact of the ECB's conventional and unconventional monetary policies on stock markets, Journal of Macroeconomics, Vol. 48, pp.101-116. DOI: 10.1016/j.jmacro.2016.02.004 
HAMORI, S., HAMORI, N., (2010), Introduction of the euro and the monetary policy of the European Central Bank, World Scientific, 2010.

HERYÁN, T., TZEREMES, P. G., (2017), The bank lending channel of monetary policy in EU countries during the global financial crisis, Economic modelling, Vol. 67, pp.10-22. DOI: 10.1016/j.econmod.2016.07.017

HOFMANN, B., TAKÁTS, E., (2015), International Monetary Spillovers, BIS Quarterly Review, September 2015, Available at SSRN: https://ssrn.com/abstract=2661596.

IM, K. S., PESARAN, M. H., Shin, Y., (2003), Testing for unit roots in heterogeneous panels, Journal of econometrics, Vol. 115, No. 1, pp.53-74. DOI: $\underline{10.1016 / \mathrm{S} 0304-}$ 4076(03)00092-7

ITO, T., (2014), We are all QE-sians now, Institute for Monetary and Economic Studies, Bank of Japan, Discussion Paper, (2014-E), Vol. 5.

JÄGER, J., GRIGORIADIS, T., (2017), The effectiveness of the ECB's unconventional monetary policy: Comparative evidence from crisis and non-crisis Euro-area countries, Journal of International Money and Finance, Vol. 78, pp.21-43. DOI: 10.1016/j.jimonfin.2017.07.021

JAMMAZI, R., FERRER, R., JARENO, F., HAMMOUDEH, S., (2017), Main driving factors of the interest rate-stock market Granger causality, International Review of Financial Analysis, Vol. 52, pp.260-280. DOI: 10.1016/j.irfa.2017.07.008

JOYCE, M., MILES, D., SCOTT, A., VAYANOS, D., (2012), Quantitative easing and unconventional monetary policy-an introduction, The Economic Journal, Vol. 122, No. 564, pp.F271-F288. DOI: 10.1111/j.1468-0297.2012.02551.X

KENOURGIOS, D., DRAKONAKI, E., DIMITRIOU, D., (2019), ECB's unconventional monetary policy and cross-financial-market correlation dynamics, The North American Journal of Economics and Finance, Vol. 50, 101045. DOI: $\underline{10.1016 / j . n a j e f .2019 .101045}$

KHOLODILIN, K., MONTAGNOLI, A., NAPOLITANO, O.,SILIVERSTOVS, B., (2009), Assessing the impact of the ECB's monetary policy on the stock markets: A sectoral view, Economics Letters, Vol. 105, No. 3, pp.211-213. DOI: 10.1016/j.econlet.2009.08.006

KISS, Á., SZILÁGYI, K., (2014), Miért más ez a válság, mint a többi? Az adósságleépítés szerepe a nagy recesszióban, Közgazdasági Szemle, Vol. 61, No. 9, pp.949-974.

KISS, G. D., CSIKI, M., VARGA, J. Z., (2019), Comparing the IMF and the ESM through Bond Market Premia in the Eurozone, Public Finance Quarterly, Vol. 64, No. 2, pp.281-296.

KREKÓ, J., BALOGH, Cs., LEHMANN, K., MÁTRAI, R., PULAI, G,, VONNÁK, B., (2012), Nemkonvencionális jegybanki eszközök alkalmazásának nemzetközi tapasztalatai és hazai lehetőségei, MNB-Tanulmányok 100., Budapest. 
KRYZANOWSKI, L., ZHANG, J., ZHONG, R., (2017), Cross-financial-market correlations and quantitative easing, Finance Research Letters, Vol. 20, pp.13-21. DOI: 10.1016/j.frl.2016.06.011

KUCHARČUKOVÁ, O. B., CLAEYS, P., VAŠÍČEK, B., (2016), Spillover of the ECB's monetary policy outside the euro area: How different is conventional from unconventional policy?, Journal of Policy Modeling, Vol. 38, No. 2, pp. 199-225. DOI: 10.1016/j.jpolmod.2016.02.002

LIPPAI-MAKRA, E., RÁDÓCZI, Zs., KOVÁCS, Zs., (2019), Intellectual capital disclosure of Hungarian and Czech Listed firms, European Financial and Accounting Journal, [forthcoming]

MAGGIO, M. D., KERMANI, A., PALMER, C., (2016), How quantitative easing works: Evidence on the refinancing channel, No. w22638, National Bureau of Economic Research.

PÁL, T., (2018), Characteristics and perspectives of the European quantitative easing, Review of Economics Theory and Practice, Vol. 13, No. 4, pp.138-167.

PELLE, A,. VÉGH, M., (2019), How has the Eurozone Changed Since its Inception?, Public Finance Quarterly, Vol. 64, No. 1, pp.127-145.

RANALDO, A., SÖDERLIND, P., (2010), Safe Haven Currencies, Review of Finance, Vol. 14, No. 3, pp.385-407. DOI: 10.1093/rof/rfq007

RIGOBON, R., (2003), Identification through heteroskedasticity, Review of Economics and Statistics, Vol. 85, No. 4, pp.777-792. DOI: 10.1162/003465303772815727

ROBINSON, T., STONE, A., (2006), Monetary Policy, Asset-Price Bubbles, and the Zero Lower Bound, In Monetary Policy with Very Low Inflation in the Pacific Rim, NBER-EASE, Vol. 15, pp.43-90. University of Chicago Press.

SÁGI, J., LENTNER, C., (2019), Post-crisis trends in household credit market behavior: evidence from Hungary, Banks and Bank Systems, Vol. 14, No. 3, pp.162-174. DOI: 10.21511/bbs.14(3).2019.14

SHIRAI, S., (2014), Japan's monetary policy in a challenging environment, Eurasian Economic Review, Vol. 4, No.1, pp.3-24. DOI: 10.1007/s40822-014-0006-1

STAVÁREK, D., (2010), Exchange Market Pressure and De Facto Exchange Rate Regimes in the Euro Candidates, Romanian Journal of Economic Forecasting, Vol. 0, No. 2, pp.119-139.

STEELEY, J. M., (2017), The effects of quantitative easing on the integration of UK capital markets, The European Journal of Finance, Vol. 23, No. 11, pp.999-1024. DOI: $\underline{10.1080 / 1351847 X .2015 .1067635}$

TAYLOR, J. B., WILLIAMS J. C., (2011), Simple and Robust Rules for Monetary Policy, in: FRIEDMAN B. M., WOODFORD M. (eds.): Handbook of Monetary Economics, Elsevier, pp.829-856. 
TAMAKOSHI, G., HAMORI, S., (2014), Co-movements among major European exchange rates: A multivariate time-varying asymmetric approach, International Review of Economics and Finance, Vol. 31, pp.105-113. DOI: 10.1016/j.iref.2014.01.016

TARAFÁS, I., (2016), Kinyílnak-e az őszirózsák? Kitekintés a válság utáni monetáris politikára, Közgazdasági Szemle, Vol. 63, No. 5, pp.548-563. DOI: $\underline{10.18414 / K S Z .2016 .5 .548}$

THORNTON, D. L., (2014), QE: is there a portfolio balance effect?, Federal Reserve Bank of St. Louis Review, Vol. 96, No. 1, pp.55-72.

VARGHESE, R., ZHANG, Y. S., (2018), A New Wave of ECB's Unconventional Monetary Policies: Domestic Impact and Spillovers, International Monetary Fund.

WANG, Y. C., WANG, C. W., HUANG, C. H., (2015), The impact of unconventional monetary policy on the tail risks of stock markets between US and Japan, International Review of Financial Analysis, Vol. 41, pp.41-51. DOI: 10.1016/j.irfa.2015.05.020

WOODFORD, M., (2012), Inflation targeting and financial stability, NBER Working Paper No.17967, National Bureau of Economic Research, 2012. 


\section{Appendix: Detailed results}

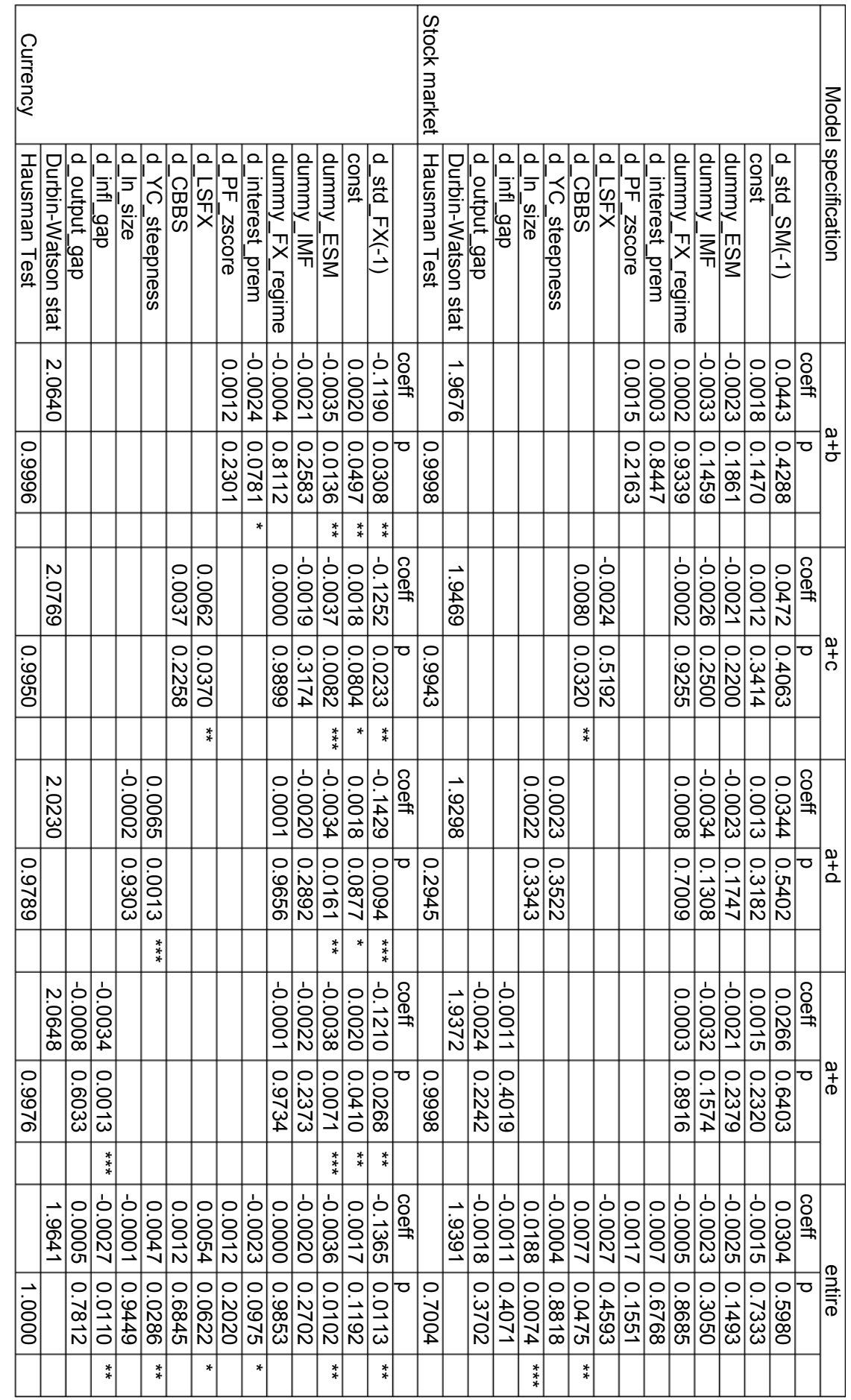




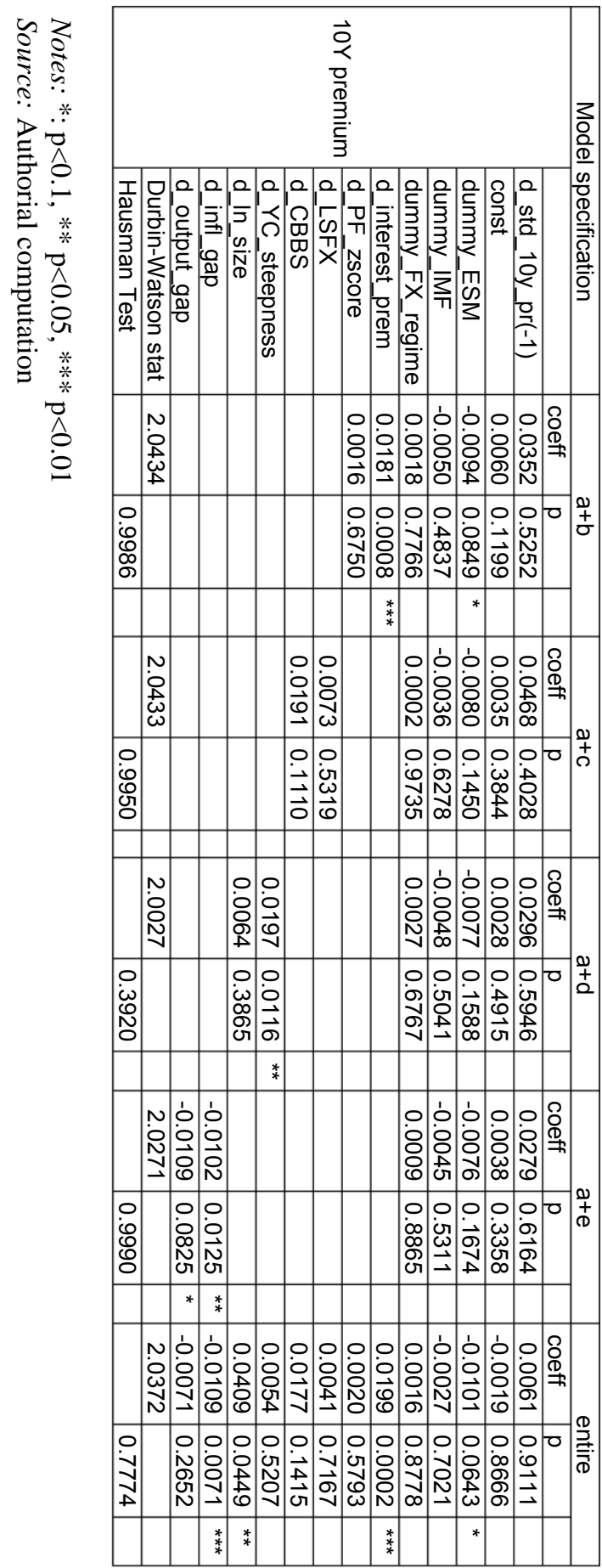

